\title{
Toxic Effects of TCDD on Osteogenesis through Altering IGFBP-6 Gene Expression in Osteoblasts
}

\author{
Lei Guo, ${ }^{*}, a$ Yu-Yan Zhaо, ${ }^{b}$ Yan-Yan Zhaо, ${ }^{c}$ Zhi-Jun Sun, ${ }^{c}$ Hong Liu, ${ }^{c}$ and Shi-Liang Zhang ${ }^{a}$ \\ ${ }^{a}$ Department of Orthopedic Surgery, First Affiliated Hospital, China Medical University; ${ }^{b}$ Department of Endocrinology, \\ First Affiliated Hospital, China Medical University; and ${ }^{c}$ Department of Medical Genetics, China Medical University; \\ Shenyang, Liaoning 110001, P. R. China. Received April 27, 2007; accepted July 2, 2007
}

Since 2,3,7,8-tetrachlorodibenzo- $p$-dioxin (TCDD) has reproductive and developmental toxicity as an estrogen antagonist, we investigated the effects of TCDD on osteogenesis in rat skeleton and the human female-responsive osteoblastic osteosarcoma cell line SaOS-2. Rat fetuses were exposed to 5, 10, or $15 \mu \mathrm{g} / \mathrm{kg}$ TCDD on gestation day (GD) 10. TCDD dose-dependently induced single or multiple rat fetal skeletal development malformations in vivo. In vitro, $10 \mathrm{nM}$ TCDD significantly inhibited cell proliferation in the presence of $1 \mu \mathrm{M} 17$ - $\beta$-estradiol (E2) in SaOS-2 cells. Insulin-like growth factor binding protein 6 (IGFBP-6), as a crucial regulator in IGF system, plays an important role in osteogenesis and bone function. TCDD $(15 \mu \mathrm{g} / \mathrm{kg})$ induced a dramatic 3-fold increase in IGFBP-6 mRNA expression in rat fetal calvaria on GD 21. On the other hand, the concurrent treatment of $10 \mathrm{~nm}$ TCDD and $1 \mu_{\mathrm{M}} \mathrm{E} 2$ resulted in a significant increase in IGFBP-6 mRNA and protein after $24 \mathrm{~h}$ in SaOS-2 cells, but TCDD and (or) E2 had no effect on the mRNA level of cytosolic aromatic hydrocarbon receptor. The functional estrogen-responsive element (ERE) [5'-CCT TCA CCT G-3'] $(-9$ to +1$)$ in the IGFBP-6 promoter region was identified in this study for the first time as the ER genomic binding site. Collectively, these results suggest that TCDD can alter the expression of IGFBP-6 gene and exerts growth-inhibitory effects on osteogenesis. In addition, TCDD exhibits an anti-estrogenic effect through its interference with the binding of activated estrogen-liganded ER to the functional ERE in IGFBP-6 gene promoter.

Key words dioxin; insulin-like growth factor binding protein 6; estrogen; estrogen response element; genetic transcription; osteoblast

2,3,7,8-Tetrachlorodibenzo- $p$-dioxin (TCDD) is a halogenated aromatic hydrocarbon that exerts reproductive toxicity, developmental teratogenic effects, and carcinogenicity. ${ }^{1-5)}$ Generally, most of the toxic effects of TCDD are mediated through specific binding to the cytosolic aromatic hydrocarbon receptor (AhR). ${ }^{6}$ ) The $\mathrm{AhR}$ is a ligand-activated basic region-helix-loop-helix transcription factor that forms a heterodimeric complex with the AhR nuclear translocator. ${ }^{78}$ This complex binds to aromatic hydrocarbon-responsive elements (AhREs, also called DREs) in the 5'-flanking region of target genes, and acts as a transcriptional activator. However, some of the functions of TCDD work independently of AhR. ${ }^{9-11)}$ Therefore, the molecular mechanisms underlying the toxicity of TCDD have not yet been fully illustrated.

TCDD is regarded as an endocrine-disrupting chemical. ${ }^{12)}$ It has been reported to exert both estrogenic and antiestrogenic effects. Several studies have shown that TCDD reduced both cellular estradiol secretion and estradiol-mediated biologic effects. ${ }^{13,14)}$ As an important endocrine-hormone, estrogen is essential for the regulation of the growth, differentiation, and function of target cells. The estrogen receptor (ER), a member of the steroid-thyroid hormone receptor superfamily, mediates its action by binding ligand dependently to the estrogen-responsive element (ERE) in the target gene promoter, regulating their transcription directly. ${ }^{15,16)}$ ER has been found in female organs and nonreproductive systems, such as the central nervous system, ${ }^{17,18)}$ cardiovascular system, ${ }^{19,20)}$ and skeletal system. ${ }^{21,22)}$ However, despite the wide variety of estrogen actions, relatively few genes that are directly responsive to this hormone have been identified.

Insulin-like growth factors (IGFs) are peptides displaying important functions in regulating cell proliferation, differen- tiation and metabolism. ${ }^{23)}$ IGFs are modulated by a family of seven high-affinity IGF binding proteins (IGFBP $1-7$ ). ${ }^{24)}$ Among them, IGFBP-6 has a 20-100 fold higher binding affinity for IGF-II over IGF-I. The overexpression of IGFBP6 inhibited neuroblastoma growth in vivo ${ }^{26)}$ and proliferation of human bronchial epithelial cells. ${ }^{27)}$ Furthermore, IGFBP-6 activated programmed cell death in non-small cell lung cancer cells. ${ }^{28)}$ In bone, both IGF-II and IGFBP-6 are potent mitogens of osteoblasts, in which the IGF system may play an integral role in skeletal development. ${ }^{29-32)}$

In an attempt to understand the underlying mechanisms of the toxic effects of TCDD on osteogenesis, we have previously investigated the regulation of TCDD on IGFBP-6 gene in vivo. ${ }^{33)}$ Here, we present evidence that IGFBP-6, as a crucial modulator of IGF bioavailability, is expressed in the rat fetal calvaria and osteoblastic osteosarcoma cell line SaOS-2, in which TCDD increased the abundance of IGFBP- 6 mRNA and exerts growth-inhibitory effects in the presence of $17-\beta$ estradiol (E2). In this study, we first examined the effects of TCDD on estrogen-mediated osteogenesis through a functional ERE on the IGFBP-6 gene promoter. These results should contribute to a better understanding of the molecular mechanisms of the osteogenetic toxicity of TCDD.

\section{MATERIALS AND METHODS}

Materials Wistar rats were provided by the Center of Experimental Animals of China Medical University. The human osteosarcoma cell line SaOS-2 was obtained from the American Type Culture Collection; TCDD was purchased from Japanese Okumetric Company; $17-\beta$-estradiol (E2), penicillin, streptomycin, alizarin red, potassium hydroxide $(\mathrm{KOH})$, dimethyl sulfoxide (DMSO), and propidium iodide 
were purchased from Sigma Chemical Corporation. Dulbecco's modified eagle's medium (DMEM) was purchased from Invitrogen Corporation (Merelbeke, Belgium). Fetal bovine serum (FCS) was purchased from Hyclone Corporation (Erebodegem-Aalst, Belgium). Rat IGFBP-6 gene probe for Northern blotting analysis was kindly provided by Dr. S. Shimasaki (Whittier Institute, La Jolla, CA, U.S.A.). The MMLV kit reverse transcription and PCR reagent were obtained from Promega Corporation; TRIZOL RNA extracting reagent was purchased from Gibco Corporation; The primers of IGFBP-6 and $\beta$-actin were synthesized by Clontech Laboratory Inc. Polyclonal anti-human IGFBP-6 antibody was purchased from Santa Cruz Biotechnology Inc. (Santa Cruz, CA, U.S.A.); and goat polyclonal anti-human actin antibody was purchased from Lab Vision Corporation (CA, U.S.A.). All other chemicals and biochemicals were purchased from commercial sources and were either reagent or molecular biology grade.

Animal Studies Twenty female Wistar rats (Department of Experimental Animals, China Medical University) weighing $220-240 \mathrm{~g}$ were raised in animal rooms under a $12 \mathrm{~h}$ light-dark cycle (lights on from 6 a.m. to 6 p.m.), at $22^{\circ} \mathrm{C}$ and $60 \%$ in relative humidity. Rats were divided and treated as previously described. ${ }^{33)}$ Briefly, the rats were divided randomly into 4 groups (5 rats per group), and pregnancy was determined by means of checking for spermatozoon in vagina. On gestation day (GD) 10, the rats were injected via the gastric canal with TCDD (Cambridge Isotope Laboratory, Inc., Japan) dissolved in mineral oil. For dose-response analyses of the effects of TCDD, the 1st group was treated with an isodose of mineral oil, the 2 nd group with $5 \mu \mathrm{g} / \mathrm{kg}$ TCDD, the 3rd group with $10 \mu \mathrm{g} / \mathrm{kg}$ TCDD, and the 4 th group with $15 \mu \mathrm{g} / \mathrm{kg}$ TCDD. On GD 21, the fetuses were removed and their degree of development was observed and recorded. The fetal calvaria tissue was used as an experimental material and stored at $-70^{\circ} \mathrm{C}$.

Cell Culture and Treatment with E2 and TCDD SaOS-2 cells (osteoblastic osteosarcoma cell line) were routinely cultivated as a monolayer in Dulbecco's modified Eagle's medium (DMEM) (Invitrogen, Merelbeke, Belgium) supplemented with 10\% fetal bovine serum (FCS) (Hyclone, Erebodegem-Aalst, Belgium) $100 \mathrm{IU} / \mathrm{ml}$ of penicillin, and $100 \mu \mathrm{g} / \mathrm{ml}$ streptomycin (Gemini Bio-Products) in an incubator with $5 \% \mathrm{CO}_{2}$ at $37^{\circ} \mathrm{C}$. When the cells had grown to the logarithmic growth phase for $24 \mathrm{~h}$, they were divided into 4 groups: the 1 st group as a control with $0.1 \%(\mathrm{v} / \mathrm{v})$ dimethyl sulfoxide (DMSO), and the 2nd to 4th group treated with $1 \mu \mathrm{M} 17-\beta$-estradiol (E2) (Sigma-Aldrich), $10 \mathrm{~nm}$ TCDD, and with both $10 \mathrm{~nm}$ TCDD and $1 \mu \mathrm{M}$ E2, respectively. TCDD and E2 were both dissolved in $0.1 \%$ DMSO to concentrations of $1 \mu \mathrm{M}$ and $100 \mu \mathrm{M}$, respectively. The cells were collected after incubation for $24 \mathrm{~h}$.

Measurement of Cell Proliferation After an initial overnight incubation, TCDD and E2 were added to the SaOS-2 cells. After $24 \mathrm{~h}$, the cells were washed and the amount of cell proliferation was determined by a 3-(4,5-dimethylthiazol-2-yl)-2,5-diphenyltetrazolium bromide (MTT) (Sigma-Aldrich) assay. The cells were washed with phosphate-buffered saline (PBS), and MTT was diluted using serum-free medium to obtain a concentration of $0.5 \mathrm{mg} / \mathrm{ml}$. This concentration was added to the culture and incubated for $3 \mathrm{~h}$. Formazan extraction was performed using isopropanol, and the quantity was determined using an enzyme linked-immunosorbent assay at $492 \mathrm{~nm}$ with four individual samples per group.

Evaluating the Effects of E2 and TCDD on IGFBP-6 by Northern Blotting Analysis The total RNA was extracted from the fetal rat calvaria tissue and SaOS-2 cells according to the manufacturer's instruction for the total RNA isolation system (Gibco). The concentrations of RNA were determined by ultraviolet absorbance at $260 \mathrm{~nm}$. RNA was fractionated by $1.5 \%$ agarose-formaldehyde gel electrophoresis in 3-( $N$-morpholino) propane sulfonic acid buffer and transferred to a nylon membrane using a capillary blotting procedure. The rat IGFBP-6 gene probe (kindly provided by Dr. S. Shimasaki, Whittier Institute, La Jolla, CA, U.S.A.) used for hybridization was labeled with $\left[\alpha-{ }^{32} \mathrm{P}\right] \mathrm{d}-\mathrm{CTP}(6000 \mathrm{Ci} /$ mmol) using a random primer. Hybridizations were carried out at $42{ }^{\circ} \mathrm{C}$ for $24 \mathrm{~h}(50 \%$ formamide, $10 \%$ dextran sulfate, $5 \times$ SSPE, $1 \%$ SDS, $1 \times$ Denhardt's solution, and $100 \mathrm{pg} / \mathrm{ml}$ salmon sperm DNA), posthybridization washes were performed at $65^{\circ} \mathrm{C}$ in $1 \times$ saline-sodium citrate (SSC). Membranes were exposed to Kodak XAR-2 film. After stripping, the membranes were rehybridized with a 650-bp $\beta$-actin probe (Clontech Laboratory, Inc.) under the same conditions. Band intensities were analyzed using Fluorchem 2.0 software (Alpha Innotech Corporation, U.S.A.). The relative amount of IGFBP-6 mRNA was determined after normalization to the levels of $\beta$-actin mRNA.

Evaluating the Effects of E2 and TCDD on IGFBP-6 by Western Blot Analysis For the immunodetection of IGFBP-6 protein, SaOS-2 cells were treated with $1 \%$ vehicle (DMSO), $10 \mathrm{~nm}$ TCDD or $1 \mu \mathrm{M}$ E2 for $24 \mathrm{~h}$ in $25-\mathrm{cm}^{2}$ flasks, and then harvested by trypsinization and resuspended in $10 \mathrm{~mm}$ Tris- $\mathrm{HCl}$ (pH 7.4), $100 \mathrm{~mm} \mathrm{NaCl}, 0.5 \%$ desoxycholic acid, and $1 \mathrm{~mm}$ dithiothreitol containing aprotinin $(10 \mu \mathrm{g} / \mathrm{ml})$ at $4{ }^{\circ} \mathrm{C}$ for $30 \mathrm{~min}$. Cells were centrifuged at $100000 \mathrm{r} / \mathrm{min}$ for $30 \mathrm{~min}$. The amount of protein was determined at $595 \mathrm{~nm}$ using a protein assay kit (BioRad, Munich, Germany). Protein extracts $(10 \mu \mathrm{g} /$ lane $)$ were run on a $12 \%$ SDS polyacrylamide gel, and separated proteins were blotted onto a nitrocellulose membrane (Amersham, Freiburg, Germany). Unbound sites were blocked overnight at $4{ }^{\circ} \mathrm{C}$ in $10 \mathrm{~mm}$ Tris and $0.15 \mathrm{M} \mathrm{NaCl}(\mathrm{pH} 7.4$; TBS) containing 5\% (wt/vol) skim milk powder. Blots were washed three times for $10 \mathrm{~min}$ each time with TBS containing $0.05 \%$ Tween-20 (TBST) and incubated for $1 \mathrm{~h}$ with the polyclonal anti-human IGFBP-6 antibody $(1: 1000)$ (Santa Cruz Biotechnology, Inc., Santa Cruz, CA, U.S.A.). For verification and quantitation of protein loading, stripped membranes were incubated with the goat polyclonal anti-human actin antibody (1:400) (Lab Vision Corporation, CA, U.S.A.). Blots were again washed three times with TBST as described above, and immunoreactive bands were visualized using the ECL plus Western blotting detection reagents (Amersham Pharmacia Biotech Inc., Piscataway, NJ, U.S.A.). The antibody-bound protein intensities were analyzed using a Chemi-imager-5500 V 2.03 electrophoresis gel image system and are shown as relative intensity values.

Induction of E2 and TCDD on IGFBP-6 by RT-PCR Total RNA was prepared from SaOS-2 cells and was used as a template for first strand cDNA synthesis using reverse tran- 
scriptase (Invitrogen). Primer sets for semi-quantitative PCR were as follows: AhR forward primer, 5'-ATA CCG AAG ACC GAG CTG AA-3'; AhR reverse primer, 5'-CCA AGT CCA TCG GTT GTT TT-3' (599 bp); $\beta$-actin forward primer, $5^{\prime}$-CGA GAT CCC TCC AAA AT AA-3'; $\beta$-actin reverse primer, 5'-TGT GGT CAT GAG TCC TTC CA-3' (294 bp). The PCR reaction mixture contained $50 \mu \mathrm{l}$ of the single-stranded cDNA product, 4 units of Vent polymerase, $1 \mu \mathrm{M}$ of each primer, $400 \mu \mathrm{M}$ each of dATP, dCTP, dGTP, and dTTP, $100 \mu \mathrm{g}$ of bovine serum albumin, $10 \mathrm{~mm}$ Tris- $\mathrm{HCl}(\mathrm{pH}$ $8.3), 50 \mathrm{~mm} \mathrm{KCl}$, and $1.5 \mathrm{~mm} \mathrm{MgCl}$ in a final volume of $100 \mu \mathrm{l}$. The mixture was amplified for 30 cycles under the following conditions: denature, $94^{\circ} \mathrm{C}, 45 \mathrm{~s}$; primer anneal, $55^{\circ} \mathrm{C}, 45 \mathrm{~s}$; primer extension, $72^{\circ} \mathrm{C}, 45 \mathrm{~s}$. The PCR products were separated on $2 \%$ agarose gel electrophoresis containing $100 \mathrm{ng} / \mathrm{ml}$ of ethidium bromide. Gels were visualized on a transilluminator and photographed by a gel-automatic formatter (GDS8000, Bio-Rad, U.S.A.). Band intensities were analyzed using Fluorchem 2.0 software (Alpha Innotech Corporation, U.S.A.). The relative amount of each sample was calculated by normalization to the levels of $\beta$-actin mRNA.

Identification of Functional ERE in IGFBP-6 Promoter by Electromobility Shift Assays (EMSA) The SaOS-2 cells were treated with $1 \%$ vehicle (DMSO), 10 nM TCDD or $1 \mu \mathrm{M}$ E2 for $24 \mathrm{~h}$, and then nuclear extracts from the SaOS-2 cells were prepared by a previously described method. ${ }^{34)}$ The concentrations of nuclear extracts were determined according to the Bradford method. ${ }^{35)}$ The putative consensus motif of EREs are mnCnsTGACC and mrCnnTGACC $(\mathrm{m}=\mathrm{A}, \mathrm{C}$; $\mathrm{n}=\mathrm{T}, \mathrm{C}, \mathrm{G}, \mathrm{A}$ ) as predicted by Transcription Element Search Software (TESS), while the sequence in human IGFBP-6 promoter DNA fragment is $5^{\prime}$-CCT TCA CCT G-3' ( -9 to $+1)$ and $5^{\prime}$-AAC CCT GAC C-3' (+105 to +115). Nucleotide numbers are denoted with the transcription start site assigned as +1 . The putative EREs probes (oligonucleotides) in human IGFBP-6 promoter were synthesized, including the wild-type ERE-1 probe (DNA sequence is 5'-CCA CCC CCC TTC ACC TGG CTC TTA A-3' and 5'-TTA AGA GCC AGG TGA AGG GG-3') ( -15 to +9$)$, wild-type ERE2 probe (DNA sequence is $5^{\prime}$-GAC GGG GCA CAA ACC CTG ACC ATG A-3' and 5'-TCA TGG TCA GGG TTT GTG CCC CGT C-3') (+94 to +119) and mutant-type ERE1 probe (DNA sequence is $5^{\prime}$-CCA CCC CCC TCC GAA CTG CTC TTA A-3' and 5'-TTA AGA GCA GTT CGG AGG GGG GTG G-3'). This mutant-type ERE-1 probe was used as a negative control, which does not contain any known binding sequences. The ERE oligonucleotides were chemically synthesized, annealed, and labeled at the $5^{\prime}$-ends by polynucleotide kinase and $\left[\gamma_{-}{ }^{32} \mathrm{P}\right] \mathrm{d}-\mathrm{ATP}(3000 \mathrm{Ci} / \mathrm{mmol})$. The labeled wild-type EREs and mutative ERE probe were incubated with $5 \mu \mathrm{g}$ of nuclear extracts and $1 \mu \mathrm{g}$ of poly $(\mathrm{dI}-\mathrm{dC}$ ) in the buffer containing $10 \mathrm{mmol} / 1$ HEPES ( $\mathrm{pH} 7.5$ ), $50 \mathrm{mml} / 1 \mathrm{KCl}, 5 \mathrm{mmol} / 1 \mathrm{MgCl}_{2}, 0.5 \mathrm{mmol} / 1$ EDTA, $1 \mathrm{mmol} / 1$ dithiothreitol, $12.5 \%$ glycerol in ice for $90 \mathrm{~min}$. Reaction mixtures were loaded onto an $8 \%$ polyacrylamide gel (acrylamide/bisacrylamide ratio, 29:1) and run at $110 \mathrm{~V}$ in $0.375 \times$ TBE $(0.09 \mathrm{M}$ Tris, $0.09 \mathrm{~m}$ borate, $2 \mathrm{~mm}$ EDTA, $\mathrm{pH}$ $8.3)$. For competition experiment, 50-fold and 100-fold molar excesses of the cold ERE probe were added to the reaction mixture before the addition of the labeled probe. To identify the specific ER in DNA-ER complexes, the $\mathrm{ER} \alpha$ antibody
(1:1000) (rabbit polyclonal $\mathrm{IgG}$ against the $\mathrm{C}$ terminus of the ER $\alpha$, Santa Cruz Biotechnology, CA, U.S.A.) was added to the reaction mixture after labeled wild-type EREs were incubated with nuclear extracts for $30 \mathrm{~min}$ at $4{ }^{\circ} \mathrm{C}$. The proteinnucleic acid complexes were identified by autoradiography for $48 \mathrm{~h}$ at $-70^{\circ} \mathrm{C}$.

Plasmid Constructs The chloramphenicol acetyltransferase (CAT) reporter constructs, -44IGFBP-6-pCAT and +29IGFBP-6-pCAT containing the human IGFBP-6 gene promoter sequences from -44 to +118 and from +29 to +118 , respectively, were prepared by PCR-amplified DNA fragments to CAT reporter plasmids derived from $\mathrm{pCAT}^{\mathrm{TM}}$ Basic (Promega E1041, U.S.A.). These two DNA fragments were amplified by PCR with the forward primers, 5'-AGT TTA GGG AAT GCC CGT-3', and 5'-CGG CTA CTT AAG ACA GAG-3', and the common reverse primer, 5'-CAT GGT CAG GGT TTG TGC CC-3', using human genomic DNA as a template. The -44 IGFBP-6-pCAT construct contains putative ERE-1 $(-9$ to +1$)$ and ERE-2 $(+105$ to +115 ) located in the promoter region of IGFBP-6 gene. In contrast, +29 IGFBP-6-CAT construct only contains the putative ERE-2, but is lacking the putative ERE-1. All constructs were confirmed by nucleotide sequence analysis (Fig. 9).

Cell Culture and Transient Cotransfection Assays The SaOS-2 cells were grown in DMEM, supplemented with $10 \% \mathrm{FBS}, 100$ units $/ \mathrm{ml}$ penicillin, and $100 \mu \mathrm{g} / \mathrm{ml}$ streptomycin. Cells were maintained in a $5 \% \mathrm{CO}_{2}, 95 \%$ air humidified atmosphere at $37^{\circ} \mathrm{C}$. For transient transfection, SaOS-2 cells were plated in 6-well plates and grown to $80 \%$ confluence, and then transfected with the $5 \mu \mathrm{g}$ reporter construct ( -44 IGFBP-6-pCAT or +29 IGFBP-6-pCAT), $0.2 \mu \mathrm{g}$ of pSG5HEO (the wild-type human $\mathrm{ER} \alpha$ expression vector, Invitrogen, U.S.A.) and $10 \mu \mathrm{l}$ Lipofectamine (Invitrogen, 11668-027, U.S.A.). $0.2 \mu \mathrm{g}$ of pSV- $\beta$-Galactosidase vector (Promega E1081, U.S.A.) was added as an internal control. After $16 \mathrm{~h}$ of transfection, the cells were grown in the presence of E2 $(1 \mu \mathrm{M})$, or TCDD (10 nM), or E2 plus TCDD for $24 \mathrm{~h}$ before harvesting. Cell extracts were prepared by three rapid freeze/thaw cycles and CAT activity was assayed using a CAT-ELISA kit (Roche, Cat. 1363 727, Germany). The transfection efficiency was normalized by measuring $\beta$ galactosidase $(\beta$-gal) activity in the extracts. $\beta$-Gal activity was measured by adding $50 \mu \mathrm{l}$ of cell lysate into $500 \mu \mathrm{l}$ buffer A $\left[100 \mathrm{~nm} \mathrm{Na} \mathrm{HPO}_{4}(\mathrm{pH} 7.2), 10 \mathrm{~mm} \mathrm{KCl}, 1 \mathrm{~mm}\right.$ $\mathrm{MgCl}_{2}, 10 \mathrm{~mm} \beta$-mercaptoethanol, and $15 \mathrm{mg} / \mathrm{ml} \beta$-D-galactoside sodium (Calbiochem, 48712, Germany)] and read at O.D. ${ }_{574}$. CAT activity is presented as a multiple of vehicle control.

Data Analysis The data are presented as the mean \pm S.E.M. One-way analysis of variance (ANOVA) followed by the post hoc Tukey-Kramer test was used to determine the difference among multiple groups. Student's $t$-test was used for analyzing differences between two groups. $p<0.05$ was accepted as the level of statistical significance.

\section{RESULTS}

TCDD-Induced Toxic Effect on Osteogenesis in Vivo and in Vitro To determine the toxic effect on osteogenesis, rat fetuses were exposed to TCDD on GD10, which is a criti- 

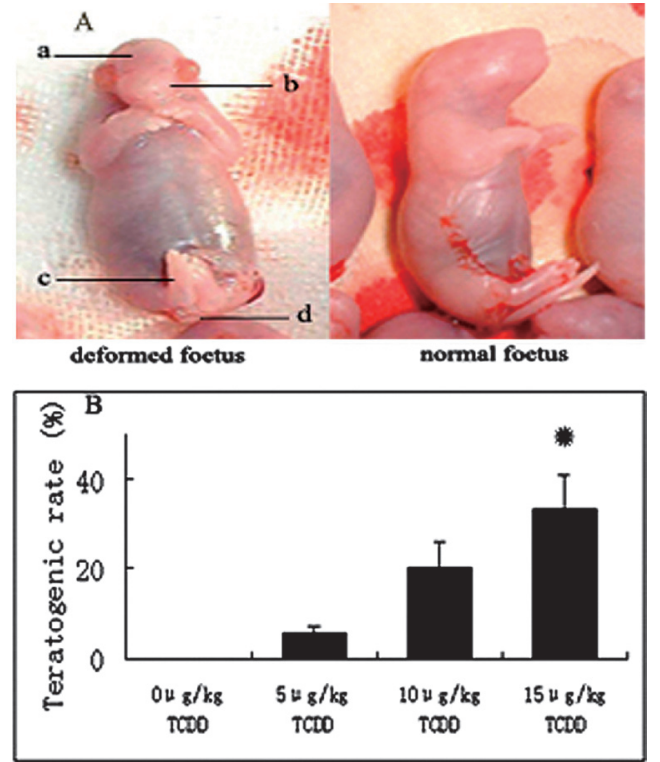

Fig. 1. Teratogenic Effect of TCDD on Rat Fetus

On GD10, the 1st group was control treated with an isodose of mineral oil, the 2nd group with $5 \mu \mathrm{g} / \mathrm{kg}$ TCDD, the $3 \mathrm{rd}$ group with $10 \mu \mathrm{g} / \mathrm{kg}$ TCDD, and the 4th group with $15 \mu \mathrm{g} / \mathrm{kg}$ TCDD. (A) Development malformations included skull growth defects (a), cleft palate (b), crossfoot and short limb malformation (c) and tailless malformations (d). (B) The rat fetus teratogenic rate in the 4th group increased significantly and was dose-dependent. $*$ Indicates significant difference from 5 and $10 \mu \mathrm{g} / \mathrm{kg}$ TCDD treatment $(p<0.05)$

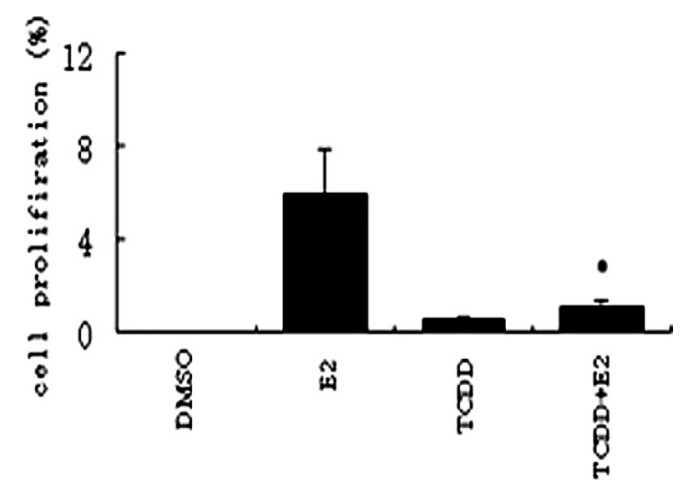

Fig. 2. TCDD Affected Cell Proliferation as an Antiestrogen

To determine the toxicity of TCDD on osteoblastic cell growth in vitro, SaOS- 2 cell proliferation was examined by MTT. As an antiestrogen, TCDD significantly inhibited SaOS- 2 cell proliferation in cells co-treated with $10 \mathrm{~nm}$ TCDD and $1 \mu \mathrm{M}$ E2. * Indicates significant difference from $1 \mu \mathrm{M}$ E2 alone $(p<0.05)$.

cal stage for rat fetal limb bud formation. Single or multiple rat fetal development malformations were induced when the rats were treated with $5-15 \mu \mathrm{g} / \mathrm{kg}$ TCDD. These malformations included crossfoot, skull growth defects, cleft palate, and lack of a tail (Fig. 1). The effect of TCDD on osteogenesis was dose-dependent (Fig. 1). On the other hand, cell proliferation in vitro in SaOS-2 cells, a female-derived osteoblastic osteosarcoma cell line, was significantly inhibited by TCDD $(10 \mathrm{nM})$ compared to treatment with E2 $(1 \mu \mathrm{M})$ (Fig. 2).

TCDD Altered IGFBP-6 Gene Expression In order to determine whether the transcription and translation of IGFBP-6 gene are regulated by TCDD, we isolated mRNA and protein from defective fetal calvaria tissue treated with TCDD. As shown in Figs. 3 and 4, TCDD resulted in signifi-
A
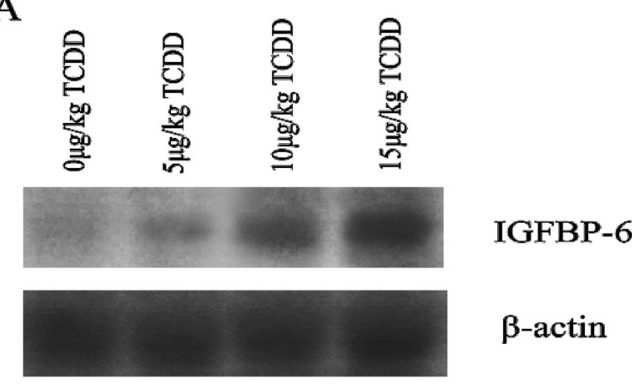

$\beta$-actin

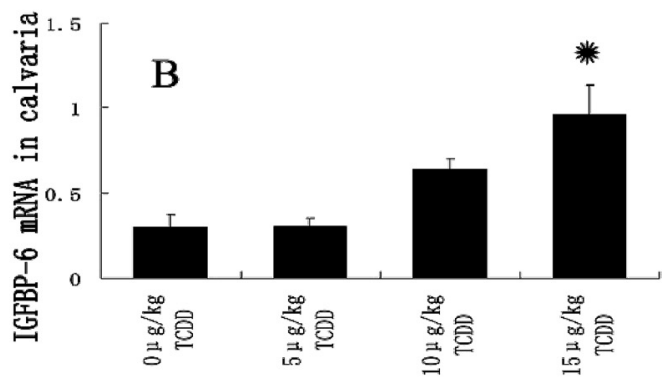

C
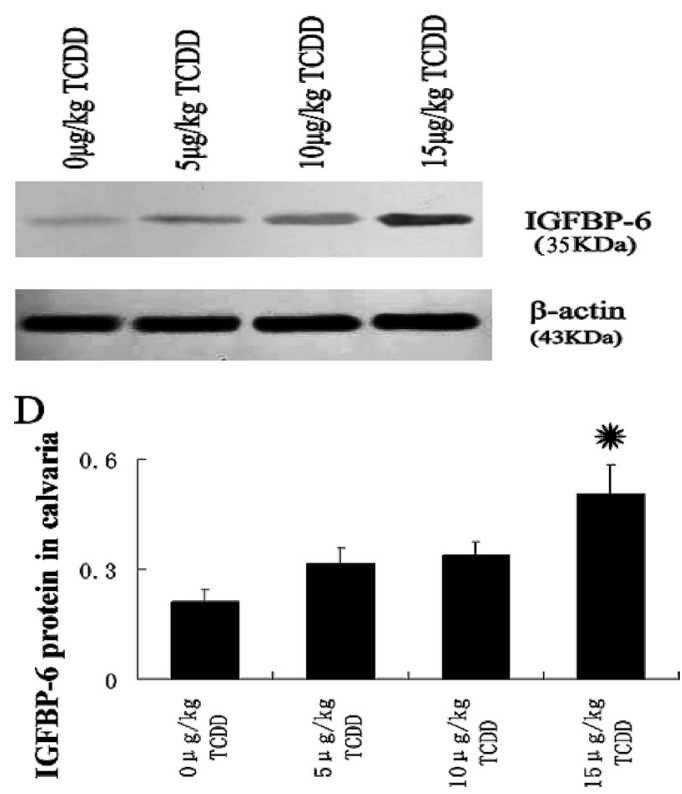

Fig. 3. TCDD-Mediated Up-Regulation of IGFBP-6 Expression in Vivo

Rat fetuses were exposed to $5-15 \mu \mathrm{g} / \mathrm{kg}$ TCDD on GD10. Total RNA and protein from fetal calvaria bone tissue were subjected to Northern blot analysis (A) and Western blot analysis (C) on GD21. (A, C) The band intensity from each sample was quantified using Fluorchem 2.0 software and is presented as a multiple of $\beta$-actin density. The experiment was carried out four times. (B, D) The data represent mean \pm S.E.M. The expression of IGFBP-6 mRNA in the TCDD-exposure group $(10-15 \mu \mathrm{g} / \mathrm{kg})$ was 3 times higher than the normal group, whereas the protein was 2 times higher. The asterisks represent significant differences from control group $(* p<0.05)$.

cant increases in IGFBP-6 mRNA and protein by Northern and Western blot analysis. At doses of $5-15 \mu \mathrm{g} / \mathrm{kg}$ in vivo, TCDD had a significant, dose-dependent effect on IGFBP-6 mRNA expression (Fig. 3). As demonstrated in Fig. 3, $15 \mu \mathrm{g} / \mathrm{kg}$ TCDD significantly increased the level of IGFBP-6 mRNA 3-fold in fetal calvaria compared to that in normal fetus.

Next, we studied the effects of TCDD and E2 on SaOS-2 cells in vitro since rat fetus is in high status of E2 on GD10. The cells were exposed to $10 \mathrm{~nm}$ TCDD and/or $1 \mu \mathrm{M}$ E2 for $24 \mathrm{~h}$. As can be seen in Fig. 4, $1 \mu \mathrm{M}$ E2 caused a significant 2 -fold decrease in the IGFBP- 6 mRNA level. On the con- 
A

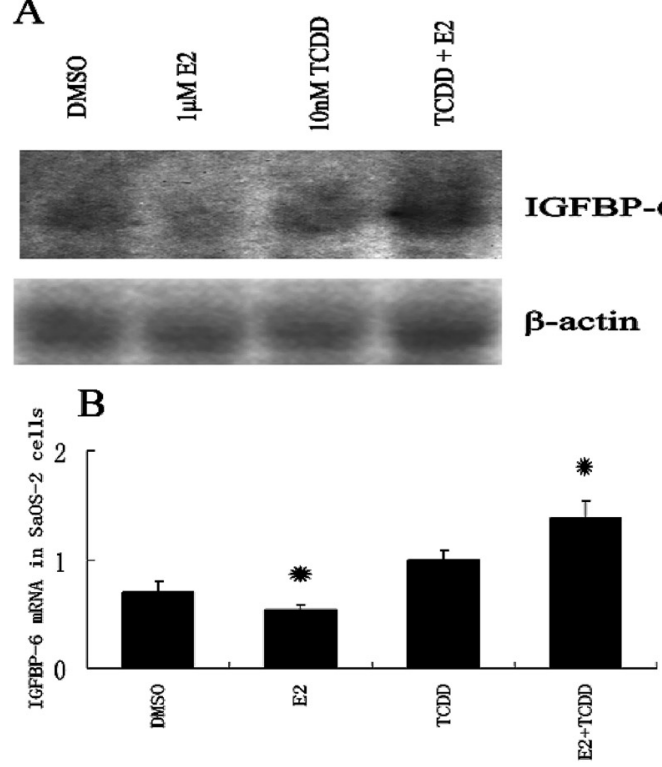

$\mathrm{C}$

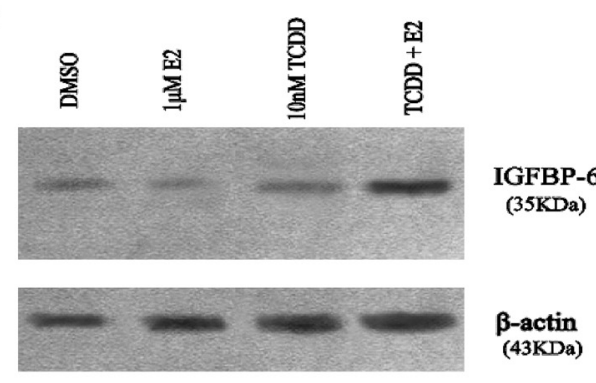

$\mathrm{D}$

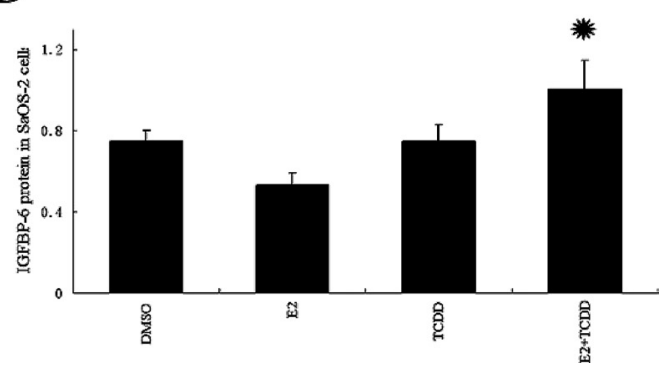

Fig. 4. Toxic Effect of TCDD on the Up-Regulation of IGFBP-6 Expression in SaOS-2 Cell Line

SaOS-2 cells were cotreated with $1 \mu \mathrm{M}$ E2, or $10 \mathrm{~nm}$ TCDD, or $10 \mathrm{~nm}$ TCDD plus $1 \mu \mathrm{M}$ E2 for $24 \mathrm{~h}$. Total RNA and protein from fetal SaOS-2 cells were subjected to Northern blot analysis (A) and Western blot analysis (C), respectively. (A, C) Band intensity from each sample was quantified using Fluorchem 2.0 software. The mRNA and protein expression of IGFBP- 6 are presented as a multiple of $\beta$-actin density. The experiment was carried out four times. (B, D) The data represent mean \pm S.E.M. The results of Northern blot analysis indicated that IGFBP-6 mRNA in SaOS-2 cells cotreated with $10 \mathrm{~nm}$ TCDD and $1 \mu \mathrm{M}$ E2 was 2.6 times higher than with $1 \mu \mathrm{M}$ E2 alone, whereas the protein was 2 times higher. The asterisks represent significant differences from control group $(* p<0.05)$

trary, TCDD $(10 \mathrm{~nm})$ induced a significant 2.6-fold increase in the mRNA level in the presence of E2. As shown in Fig. 4, $10 \mathrm{~nm}$ TCDD and $1 \mu \mathrm{M}$ E2 resulted in significant 2-fold increases in IGFBP-6 protein in SaOS-2 cells by Western blot analysis compared with treatment by E2 alone.

Since the toxic effects of TCDD are mediated through specific binding to the AhR, ${ }^{6-8)}$ we investigated AhR mRNA expression in SaOS-2 cells. As shown in Fig. 5, AhR mRNA was expressed in SaOS-2 cells and was not changed by exposure to TCDD and (or) E2. Taken together, these results

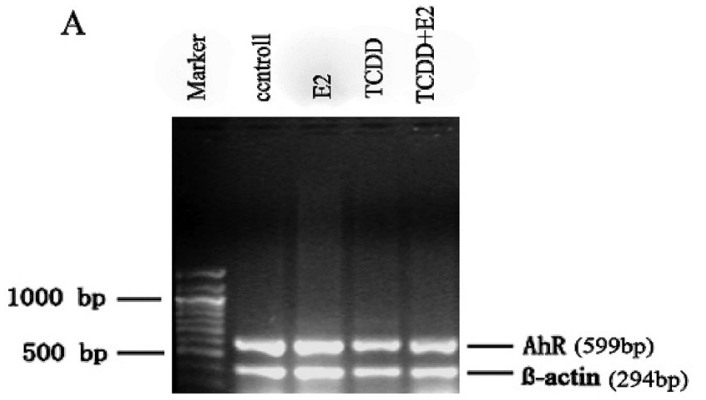

B

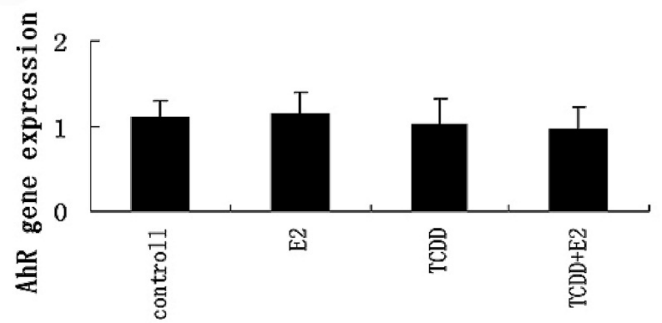

Fig. 5. Expression of AhR in SaOS-2 Cells Treated with $10 \mathrm{~nm}$ TCDD and (or) E2

SaOS-2 cells were harvested $24 \mathrm{~h}$ after exposure to $10 \mathrm{~nm}$ TCDD and (or) E2, or $0.1 \%(\mathrm{v} / \mathrm{v})$ DMSO as a control. (A) After total RNA was isolated, the specific cDNAs were amplified by semi-quantitative RT-PCR using the number of cycles indicated. Representative data are shown from three independent experiments. (B) The relative amount of each sample was calculated as a multiple of relative $\beta$-actin density. The data represent mean \pm S.E.M. AhR mRNA was expressed in SaOS-2 cells and was not significantly changed by exposure to TCDD and (or) E2.

demonstrated that the transcription and translation of IGFBP6 gene were positively regulated by TCDD in vitro and in vivo.

Teratogenic Effect of TCDD through Functional ERE Located in the IGFBP-6 Gene Promoter IGFBP-6 gene expression was regulated by E2 and TCDD at transcriptional level in vivo and in vitro. Sequence analysis was carried out to search for DREs or EREs in the $1.8 \mathrm{~kb}$ region of the human IGFBP-6 gene promoter (GenBank access numbers AF297519). We did not find the DREs located in the IGFBP6 gene promoter using TESS, but the two putative EREs in IGFBP-6 gene promoter were identified. The putative EREs sequences were $5^{\prime}$-CCT TCA CCT G-3' $(-9$ to +1$)$ and $5^{\prime}$ AAC CCT GAC C-3' (+105 to +115). To examine the function of these two putative EREs, two constructed pCAT vectors (containing these putative EREs) were transiently cotransfected to SaOS-2 cells with an ER $\alpha$ expression vector. As shown in Fig. 9, $10 \mathrm{~nm}$ TCDD significantly increased the CAT activity in -44 IGFBP-6-pCAT [containing ERE-1 (-9 to +1$)$ and ERE-2 $(+105$ to +115$)$ ] transfected cells, but not in +29 IGFBP-6-pCAT [only containing ERE-2 (+105 to $+115)$ ] transfected cells. Similar to the TCDD induction of IGFBP-6 mRNA in the SaOS-2 cells, 10 nm TCDD induction of CAT activity in -44 IGFBP-6-pCAT transfected cells increased 3-fold compared to those cotreated with $1 \mu \mathrm{M}$ E2 (data not shown). Neither $0.1 \%$ DMSO nor $10 \mathrm{~nm}$ TCDD alone altered CAT activity in the -44 IGFBP-6-CAT transfected cells. Ten nanomolar TCDD and $1 \mu \mathrm{M}$ E2 did not induce a change in CAT activity in the +29IGFBP-6-CAT transfected cells (Fig. 9). These results indicate that the functional ERE-1 $(-9$ to +1$)$ is located in the IGFBP-6 gene promoter. In the presence of E2 and ER, TCDD can up-regu- 


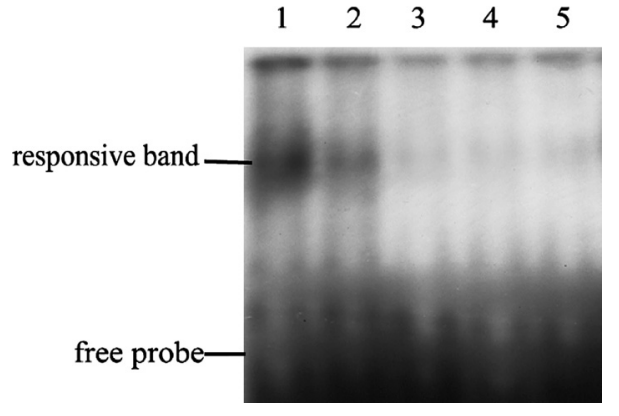

Fig. 6. Binding of ER to the ERE of the IGFBP-6 Gene (EMSA)

Nuclear extracts from SaOS-2 cells were incubated with ${ }^{32} \mathrm{P}$-labeled probe harboring the ERE (Lane 1-5) of the IGFBP-6 gene as described in the "Materials and Methods." The resulting complexes were resolved by nondenaturing PAGE. Labeled mutanttype ERE-1 probe was used as a negative control (Lane 5). For competition EMSA, 50 -fold and 100-fold excess of unlabeled probe harboring the wild-type ERE-1 (Lane 2,3 ) of the IGFBP- 6 gene promoter was added during the preincubation period. The responsive banding (see arrow, showed in Fig. 5) of wild-type ERE-1 binding complex was observed. The addition of a cold consensus ERE-1 (Lane 2,3) decreased or eliminated the formation of specific complexes. The retarded band of mutant-type ERE-1 binding complex was not observed when labeled mutant-type ERE-1 was incubated with nuclear extracts (Lane 5). The line indicates ER binding. Lane 1: wild-type ERE-1 incubated with nuclear protein from SaOS-2 cells; Lane 2: 50-fold excess of unlabeled wild-type ERE-1 incubated with nuclear protein; Lane 3: 100-fold excess of unlabeled wild-type ERE-1 incubated with nuclear protein; Lane 4: mutant-type ERE-1 incubated with nuclear protein; Lane 5: wild-type ERE-2 incubated with nuclear protein from $\mathrm{SaOS}-2$ cells.

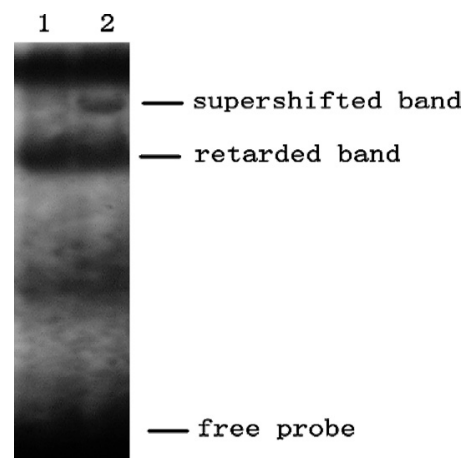

Fig. 7. Interaction of ER $\alpha$ Antibody with IGFBP-6 Gene Promoter

A representative EMSA performed as described in the "Materials and Methods." The ER $\alpha$ antibody was bound to the putative ERE-1-ER complexes. These specific complexes (Lane 2) were delayed and formed a supershifted band, compared with ERE1-ER complexes (Lane 1). This experiment was performed in duplicate with similar results, and a representative band is shown. Lane 1: wild-type ERE-1 incubated with nuclear protein from SaOS-2 cells; Lane 2: wild-type ERE-1 and ER $\alpha$ antibody incubated with nuclear protein.

late the CAT activity through ERE-1 $(-9$ to +1$)$ in the IGFBP-6 gene promoter.

To determine whether the identified activated ER-protein can bind to these putative EREs in IGFBP-6 gene promoter, the direct and competitive binding of the wild-type and mutant-type EREs oligonucleotides with nuclear extracts was determined by EMSA (Figs. 6,7). The efficient retarded band was shown under adding the labeled ERE-1 probe (Fig. 6, Lane 1), indicating that activated ER-protein can directly interact with this natural ERE-1. In competitive binding studies, this retarded band was competed by the 50 or 100 -fold excess of unlabeled ERE-1 probe (Fig. 6, Lane 2, 3). Addition of the nonspecific labeled probe (mutant-type ERE-1 oligonucleotides) did not result in binding (Fig. 6, Lane 4). Similar retarded band was not shown, when labeled wildtype ERE-2 probe were incubated with nuclear extracts (Fig. 6, Lane 5). To identify the specific ER in DNA-ER com-

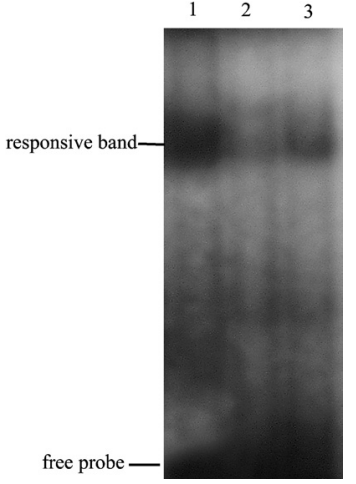

Fig. 8. TCDD Affected Binding of ER to the ERE of the IGFBP-6 Gene (EMSA)

Nuclear extracts from SaOS-2 cells treated with $1 \mu \mathrm{M}$ E2 or $10 \mathrm{~nm}$ TCDD (Lane 13 ) were incubated with ${ }^{32} \mathrm{P}$-labeled probe harboring the wild-type ERE-1 of the IGFBP6 gene as described in the "Materials and Methods." The retarded band of ER binding complex was not observed when labeled wild-type ERE-1 was incubated with nuclear extracts from SaOS-2 cells treated with $10 \mathrm{~nm}$ TCDD (Lane 2). The retarded band of ER binding complex was significantly decreased when labeled wild-type ERE-1 was incubated with nuclear extracts from SaOS-2 cells co-treated with $10 \mathrm{~nm}$ TCDD and $1 \mu \mathrm{m}$ E2 (Lane 3). This experiment was performed in duplicate with similar results, and a representative blot is shown. The line indicates ER binding. Lane 1: wild-type ERE-1 incubated with nuclear protein from SaOS-2 cells; Lane 2: wild-type ERE-1 incubated with nuclear protein from SaOS-2 cells treated with $10 \mathrm{~nm}$ TCDD; Lane 3: wild-type ERE-1 incubated with nuclear protein from SaOS-2 cells co-treated with $10 \mathrm{~nm}$ TCDD and $1 \mu_{\mathrm{M}} \mathrm{E} 2$.

plexes, ER $\alpha$ antibody was used in EMSA. As shown in Fig. 7, $\mathrm{ER} \alpha$ antibody specifically bound to labeled DNA-ER complexes and formed supershifted bands (Fig. 7, Lane 2).

To identify the influence of TCDD on the binding of ER to the ERE of the IGFBP- 6 gene, the direct binding of the wildtype ERE-1 oligonucleotides with nuclear extracts was determined by EMSA (Fig. 8). The retarded band of ER binding complex was not observed when labeled wild-type ERE-1 was incubated with nuclear extracts from SaOS-2 cells treated with $10 \mathrm{~nm}$ TCDD (Fig. 8, Lane 2). The retarded band was significantly decreased when ERE-1 was incubated with nuclear extracts co-treated with $10 \mathrm{~nm}$ TCDD and $1 \mu \mathrm{M}$ E2 (Fig. 8, Lane 3). These results indicate that ER-DNA binding was affected by TCDD in SaOS-2 cells.

Collectively, these data show that the functional ERE-1 $(-9$ to +1$)$ in the promoter region of IGFBP- 6 gene is able to bind activated ER. Moreover, in SaOS-2 cells, TCDD may alter the IGFBP-6 gene expression and exhibit anti-estrogenic effects by regulating the binding of activated ER to this functional ERE in IGFBP-6 gene promoter.

\section{DISCUSSION}

TCDD is an environmental contaminant that has a wide spectrum of toxic effects, including fetotoxicity and teratogenicity. ${ }^{36-39)}$ Although these effects on a variety of tissues have been reported, few studies have focused on bone development. As an inhibitor, TCDD (1 nM) inhibited osteodifferentiation in a chicken periosteal osteogenesis model, in which TCDD also inhibited bone-associated protein, such as collagen type I, bone sialoprotein and alkaline phosphatase. $^{40)}$ Furthermore, TCDD dramatically suppressed post-confluent formation of multicellular nodules that developed bone tissue-like organization, but did not inhibit osteoblast proliferation. ${ }^{41)}$ Induction of cleft palate in mice occurs with peak incidence when TCDD is administered on GD 

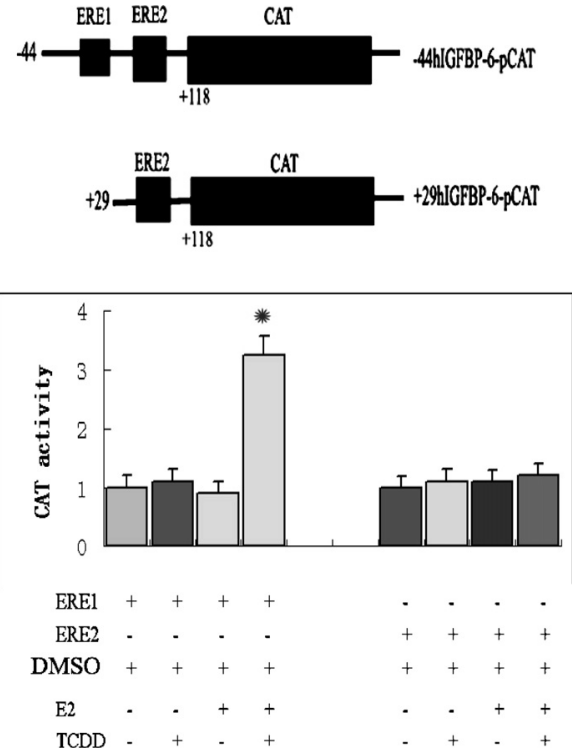

Fig. 9. Plasmid Constructs and Promoter Activity of the Human IGFBP-6 Gene

PCR products from the human IGFBP-6 gene promoter were inserted upstream from the luciferase gene in the promoterless $\mathrm{pCAT}^{\mathrm{TM}}$-Basic vector. In a schematic representation of the constructs (above panel), putative transcription activation sites are indicated: ERE-1 and ERE-2. These constructs were cotransfected with ER $\alpha$ expression vector into SaOS-2 cells as described in the "Materials and Methods". The transfected cells were then treated with either vehicle control $(0.1 \%(\mathrm{v} / \mathrm{v})$ DMSO $)$, E2 $(1 \mu \mathrm{M})$ or TCDD (10 M) for $24 \mathrm{~h}$. Cellular extracts were prepared and b-gal and CAT activities determined. The CAT activity was normalized to b-gal units and is presented as a multiple of vehicle control. CAT activities are expressed as the mean \pm S.E.M. for three separate determinations in each treatment group. Statistical significance of differences between groups was determined. * Indicates significant difference between the construct and the control group. $10 \mathrm{~nm}$ TCDD induction of CAT activity in -44 IGFBP-6-pCAT transfected cells increased 3-fold of control at $1 \mu \mathrm{M}$ E2. Neither $1 \mu \mathrm{M}$ E2 nor $10 \mathrm{~nm}$ TCDD alone significantly altered CAT activity in the -44 IGFBP-6-CAT transfected cells $10 \mathrm{~nm}$ TCDD and $1 \mu \mathrm{M}$ E2 did not induce any change in CAT activity in the +29IGFBP-6-CAT transfected cells.

11 and GD $12 .{ }^{42)}$ In this study, the toxic effect of TCDD was begun on GD10, which was a critical stage for rat limb bud formation. On GD21, single or multiple malformations in rat fetus included crossfoot, short limb malformation, and tailless malformations (Fig. 1). Moreover, we found that TCDD (10 nM) significantly inhibited the up-regulation of E2 on cell proliferation in an osteoblastic-like cell line. The development and differentiation of osteoblasts are known to exert profound effects on skeletal growth and development, as well as bone turnover. Osteoblasts play an important role in skeletal development and osteogenesis, and are responsible for skeletal malformations (including vertebrae, base of skull and the thinner and hypoplastic calvaria). ${ }^{43,44)}$ Therefore, we suggest that the toxic effects of TCDD may interfere with rat bone development and lead to teratogenicity.

There are many growth factors involved in the control and regulation of metabolism in bone development. IGFBP-6, a crucial regulator in the IGF system, has been shown to play an important role in osteogenesis and bone function..$^{33,45,46)}$ IGFBP-6 has a 100-fold higher binding affinity for IGF-II over IGF-I, thus it is known as a specific moderator of IGFII. $^{25)}$ The proliferation and differentiation of bone marrow mesenchymal cells are associated with IGFBP- 6 and other components of the IGF system. ${ }^{47)}$ In this study, we found that TCDD up-regulated IGFBP-6 mRNA in rat fetal deformed calvaria tissue on GD21. Growing evidence suggests that estrogen levels are high in embryonic rat fetuses. Estrogen, an important sex hormone, plays a crucial role in embryogenesis and the development of various tissues. ${ }^{48-50)}$ TCDD, as an environmental teratogenic estrogen antagonist, may play a role in teratogenic toxicity in osteogenesis by interfering with the biological effects of estrogen. In a previous study, we reported that estrogen could regulate positively the gene expression of IGF-II in MC-3T3-E1 cells, and significantly inhibited the gene expression of IGFBP-6 mRNA. ${ }^{33)}$ Studies by Park and coworkers have shown that the TCDD-up-regulation of the IGFBP-6 gene and IL-5R alpha genes was observed with EL-4 mouse thymoma cells, while IGFBP-6 mediates the immunotoxic effects of TCDD in EL-4 cells in an AhR-independent pathway. ${ }^{51,52)}$ However, TCDD can positively regulate some gene expression and cell proliferation as an estrogenic-like agent. Partridge et al. ${ }^{53)}$ have reported that TCDD (1 nM) and E2 $\left(10^{8-10} \mathrm{M}\right)$ have similar abilities to stimulate the induction of collagenase- 3 mRNA in UMR 106-01 cells. We believe that TCDD is not antiestrogenic at low physiological concentrations in vitro. The toxic action of TCDD may be correlated with cell species, cell cycle stage, and TCDD concentration, among others.

Estrogen has been reported to have an effect on osteoblastic cells, regulating some gene expression and the activities of proteins such as enzymes, bone matrix proteins, hormone receptors, and transcription factors. However, the results concerning some effects have been conflicting. It is well established that osteoblasts contain both $\operatorname{ER} \alpha$ and $\operatorname{ER} \beta$ estrogen receptors. ${ }^{54,55)}$ In addition, the level of ER $\alpha$ has been shown to increase during osteoblastic cell differentiation. ${ }^{56)}$ Stimulation of estrogen-induced gene expression in response to estrogen is mediated by the "classical" mechanism, whereby estrogen-liganded ER binds directly to the ERE, and interacts with coactivator proteins and components of the RNA polymerase II transcription machinery, resulting in enhanced or inhibited transcription. The consensus ERE contains a palindrome of PuGGTCA motifs separated by 3 bp. $^{57,58)}$ In this study, estrogen-induction of IGFBP-6 mRNA in SaOS-2 cells suggests that estrogen may act directly or indirectly on IGFBP-6 gene transcription. By analyzing the human IGFBP-6 gene promoter sequences, two putative EREs (from -9 to +1 , and from +105 to +115 ) in the proximal region of the promoter were tentatively identified. The deletion analysis in transient transfection and EMSA demonstrated that estrogen-liganded ER can bind to the specific functional ERE-1 (from -9 to +1 ) located in IGFBP-6 gene promoter and down-regulate the IGFBP-6 gene transcription.

Since the TCDD-mediated induction of the target gene transcription requires TCDD-liganded AhR, we evaluated the expression of AhR in SaOS-2 cells. Surprisingly, we found that the AhR mRNA was expressed in SaOS-2 cells. However, we were unable to demonstrate any significant differences between controls and cells treated with TCDD or E2 for $24 \mathrm{~h}$. This result led us to hypothesize that AhR mRNA is in a stable state in the osteoblastic osteosarcoma cell line. However, in rat granulosa cells, AhR mRNA was up-regulated by TCDD (3.1 nM) after $48 \mathrm{~h}$ of culturing. ${ }^{59)}$ Variations in AhR mRNA may be cell line specific. AhR has been reported to be expressed in rat osteoblast-like cells and mouse calvarial clonal preosteoblastic cells. ${ }^{60)}$ The expression of AhR in osteoblasts implies that osteoblasts are potential targets for dioxin. As a highly toxic activator, TCDD can bind 
to and activate the AhR. This ligand-activated transcription factor translocates to the nucleus and heterodimerizes with the ARNT to produce its transcriptional action. ${ }^{61,62)}$ In IGFBP-6 gene promoter, we have not found-DREs using the TESS, so how does TCDD alter the bioactivity of estrogen and ER in the regulation of IGFBP-6 gene transcription? Klinge et $a l .{ }^{63)}$ reported that the TCDD-AhR complex can block ER-ERE binding, and there are physical interactions between the AhR and ER. In human MCF-7 breast cancer cells, TCDD-AhR-ARNT complexes have been shown to associate directly with ER- $\alpha$, resulting in transcriptional activation of ERE-dependent genes. ${ }^{64)}$ In the presence of an activated $A h R$, the interaction between AhR and ER occurs at various levels and includes-DNA-binding to EREs, ${ }^{65)}$ and altered estrogen metabolism. ${ }^{66,67)}$ In this report, we found that TCDD induced an increase in IGFBP- 6 gene expression in the presence of $1 \mu \mathrm{M}$ E2; but TCDD alone did not enhance transcription of the IGFBP-6 gene (Fig. 4). Therefore, we believe that TCDD exhibits antiestrogenic effects on IGFBP-6 gene transcription with activated TCDD-liganded AhR, which interferes with the binding of activated estrogenliganded ER to the functional ERE in the IGFBP-6 gene promoter.

In summary, the results indicate dioxin has a toxic effect on osteogenesis in vivo and in vitro. As the ER genomic binding sites, the functional ERE (5'-CCT TCA CCT G-3', -9 to +1$)$ in the IGFBP-6 promoter region is required for down-regulation of estrogen to IGFBP-6 gene transcription. Furthermore, we believe that TCDD increases the level of IGFBP-6 mRNA expression and exerts growth inhibitory effects in rat fetal calvaria and SaOS-2 cells in the presence of estrogen. The mechanisms associated with inhibition of other estrogen-induced genes by TCDD in osteoblasts are unknown and are currently being investigated in our laboratory.

Acknowledgements The authors thank Dr. S. Shimasaki for kindly providing the IGFBP-6 gene probe for Northern blotting analysis. This study was financially supported by the National Natural Science Foundation of China (No. 30500414) and the Scientific Research Project of the Department of Education of Liaoning Province (No. 05L508).

\section{REFERENCES}

1) Wade M. G., Foster W. G., Younglai E. V., McMahon A., Leingartner K., Yagminas A., Blakey D., Fournier M., Desaulniers D., Hughes C. L., Toxicol. Sci., 67, 131-143 (2002).

2) Sommer R. J., Hume A. J., Ciak J. M., Vannostrand J. J., Friggens M., Walker M. K., Toxicol. Sci., 83, 363-371 (2005).

3) Bock K. W., Kohle C., Biochem. Pharmacol., 69, 1403-1408 (2005).

4) Drahushuk A. T., Choy C. O., Kumar S., McReynolds J. H., Olson J. R., Toxicology, 120, 197-205 (1997).

5) Huff J., Lucier G., Tritscher A., Annu. Rev. Pharmacol. Toxicol., 34, $343-372$ (1994)

6) Tritscher A. M., Goldstein J. A., Portier C. J., Mccoy Z., Clark G. C., Lucier G. W., Cancer Res., 52, 3436-3442 (1992).

7) Burbach K. M., Poland A., Bradfield C. A., Proc. Natl. Acad. Sci. U.S.A., 89, 8185-8189 (1992).

8) Swanson H. I., Bradfield C. A., Pharmacogenetics, 3, 213-230 (1993).

9) Hossain T., Tsuchiya S., Minegishi M., Osada M., Ikawa S., Tezuka F. A., Kaji M., Konno T., Watanabe M., Kikuchi H., J. Biol. Chem., 273, $19853-19858$ (1998).

10) Lin T. M., Ko K., Moore R. W., Buchanan D. L., Cooke P. S., Peterson R. E., J. Toxicol. Environ. Health, 64, 327-342 (2001).
11) Tan Z., Chang X., Puga A., Xia Y., Biochem. Pharmacol., 64, 771780 (2002).

12) Hutz R. J., Reprod. Dev., 45, 1-12 (1999).

13) Petroff B. K., Gao X., Rozman K. K., Terranova P. F., Reprod. Toxicol., 14, 247-255 (2000).

14) Sarkar S., Jana N. R., Yonemoto C., Tohyama C., Sone H., Int. J. Oncol., 16, 141-147 (2000)

15) Evans R. M., Science, 240, 889-895 (1988).

16) Green S., Chambon P., Trends Genet., 4, 309-314 (1988).

17) Brown T. J., Hochberg R. B., Zielinski J. E., Maclusky N. J., Endocrinology, 123, 1761-1770 (1988).

18) Simerly R. B., Chang C., Muramatsu M., Swanson L. W., J. Comp Neurol., 294, 76-95 (1990).

19) Orimo A., Inoue S., Ikegami A., Hosoi T., Akishita M., Ouchi Y., Muramatsu M., Orimo H., Biochem. Biophys. Res. Commun., 195, $730-736$ (1993).

20) Stumpf W. E., Sar M., Aumuller G., Science, 196, 319-321 (1977).

21) Eriksen E. F., Colvard D. S., Berg N. J., Graham M. L., Mann K. G., Spelsberg T. C., Riggs B. L., Science, 241, 84-86 (1988).

22) Komm B. S., Christopher M. T., Terpening M., Benz D. J., Greme K A., Gallegos M. R., Science, 241, 81-84 (1988).

23) Jones J. I., Clemmons D. R., Endocr. Rev., 16, 3-34 (1995).

24) Oh Y., Nagalla S. R., Yamanaka Y., Kim H. S., Wilson E., Rosenfeld R. G., J. Biol. Chem., 271, 30322-30325 (1996).

25) Bach L. A., Horm. Metab. Res., 31, 226-234 (1999).

26) Bienvenu G., Seurin D., Grellier P., Froment P., Baudrimont M., Monget P., Le B. Y., Babajko S., Endocrinology, 145, 2412-2420 (2004).

27) Sueoka N., Lee H. Y., Walsh G. L., Fang B., Ji L., Roth J. A., LaPushin R., Hong W. K., Cohen P., Kurie J. M., Am. J. Respir. Cell Mol. Biol., 23, 297-303 (2000).

28) Sueoka N., Lee H. Y., Wiehle S., Cristiano R. J., Fang B., Ji L., Roth J. A., Hong W. K., Cohen P., Kurie J. M., Oncogene, 19, 4432-4436 (2000).

29) Fisher M. C., Meyer C., Garber G., Dealy C. N., Bone, 37, 741-750 (2005).

30) Cheng S. L., Zhang S. F., Mohan S., Lecanda F., Fausto A., Hunt A H., Canalis E., Avioli L. V., J. Cell Biochem., 71, 449-458 (1998).

31) McCarthy T. L., Ji C., Casinghino S., Centrella M., J. Cell Biochem., 68, 446-456 (1998).

32) Wang J., Chin E., Zhou J., Bondy C. A., Endocrinology, 136, $2741-$ 2751 (1995).

33) Guo L., Zhao Y. Y., Dong L. Y., Ding Q., Sun K. L., Ji S. J., Zhonghua Yi Xue Yi Chuan Xue Za Zhi, 20, 490_494 (2003).

34) Dignam J. D., Lebovitz R. M., Roeder R. G., Nucleic. Acids Res., 11, 1475-1489 (1983).

35) Bradford M. M., Anal. Biochem., 72, 248-254 (1976).

36) Hassoun E. A., Walter A. C., Alsharif N. Z., Stohs S. J., Toxicology, 124, 27-37 (1997).

37) Thackaberry E. A., Nunez B. A., Ivnitski-Steele I. D., Friggins M., Walker M. K., Toxicol. Sci., 88, 242-249 (2005).

38) Miettinen H. M., Huuskonen H., Partanen A. M., Miettinen P., Tuomisto J. T., Pohjanvirta R., Tuomisto J., Toxicol. Lett., 150, 285291 (2004).

39) Wu Q., Ohsako S., Ishimura R., Suzuki J. S., Tohyama C., Biol. Reprod., 70, 1790-1797 (2004).

40) Singh S. U., Casper R. F., Fritz P. C., Sukhu B., Ganss B., Girard B. J., Savouret J. F., Tenenbaum H. C., J. Endocrinol., 167, 183-195 (2000).

41) Gierthy J. F., Silkworth J. B., Tassinari M., Stein G. S., Lian J. B., J. Cell Biochem., 54, 231-238 (1994).

42) Couture L. A., Abbott B. D., Birnbaum L. S., Teratology, 42, 619627 (1990).

43) Raouf A., Seth A., Oncogene, 55, 6455-6463 (2000).

44) Sumarsono S. H., Wilson T. J., Tymms M. J., Venter D. J., Corrick C. M., Kola R., Lahoud M. H., Papas T. S., Seth A., Kola I., Nature (London), 379, $534-537$ (1996).

45) Milne M., Quail J. M., Rosen C. J., Baran D. T., J. Cell Biochem., 81, 229-240 (2001).

46) Schmid C., Keller C., Gosteli-Peter M., Zapf J., Biochem. Biophys. Res. Commun., 263, 786-789 (1999).

47) Baddoo M., Hill K., Wilkinson R., Gaupp D., Hughes C., Kopen G. C., Cell Biochem., 89, 1235-1249 (2003).

48) Nautiyal J., Kumar P. G., Laloraya M., Biochem. Biophys. Res. Commun., 318, 103-112 (2004). 
49) Ma W. G., Song H., Das S. K., Paria B. C., Dey S. K., Proc. Natl. Acad. Sci. U.S.A., 100, 2963-2968 (2003).

50) Cummings A. M., Laws S. C., Reprod. Toxicol., 14, 111-117 (2000).

51) Park J. H., Hahn E. J., Kong J. H., Cho H. J., Yoon C. S., Cheong S W., Oh G. S., Youn H. J., Toxicol. Lett., 145, 55-68 (2003).

52) Park J. H., Lee S. W., Kim I. T., Shin B. S., Cheng S. W., Cho U. H., Huh M. J., Oh G. S., Mol. Cells, 12, 372-379 (2001).

53) Partridge N. C., Fiacco G. J., Walling H. W., Barmina O. Y., Jeffrey J. J., Ruh M. F., Arch. Biochem. Biophys., 382, 182-188 (2000).

54) Spelsberg T. C., Subramaniam M., Riggs B. L., Khosla S., Mol. Endocrinol., 13, 819-828 (1999).

55) Arts J., Kuiper G. G., Janssen J. M., Gustafsson J. A., Lowik C. W., Pols H. A., Leeuwen J. P., Endocrinology, 138, 5067-5070 (1997).

56) Bodine P. V., Henderson R. A., Green J., Aronow M., Owen T., Stein G. S., Lian J. B., Komm B. S., Endocrinology, 139, 2048-2057 (1998).

57) Nardulli A. M., Romine L. E., Carpo C., Greene G. L., Rainish B., Mol. Endocrinol., 10, 694-704 (1996).

58) Kuntz M. A., Shapiro D. J., J. Biol. Chem., 272, 27949-27956 (1997)
59) Asok K. D., Barbara A. B., Amanda L. T., Reinhold J. H., Mol. Cell. Endocrinol., 182, 39-48 (2001).

60) Naruse M., Ishihara Y., Miyagawa S., Koyama A., Hagiwara H., Endocrinology, 143, 3575-3581 (2002).

61) Reyes H., Reisz S., Hankinson O., Science, 256, 1193 -1195 (1992).

62) Schmidt J. V., Bradfield C. A., Annu. Rev. Cell Dev. Biol., 12, 55-89 (1996).

63) Klinge C. M., Kaur K., Swanson H. I., Arch. Biochem. Biophys., 373, $163-174$ (2000).

64) Ohtake F., Takeyama K., Matsumoto T., Kitagawa H., Yamamoto Y., Nohara K., Tohyama C., Krust A., Mimura J., Chambon B., Yanagisawa J., Fujii-Kuriyama Y., Kato S., Nature (London), 423, 545-550 (2003).

65) Safe S., Wang F., Porter W., Duan R., McDougal A., Toxicol. Lett., 102, 343-347 (1998).

66) Hayes C. L., Spink D. C., Spink B. C., Cao J. Q., Walker N. J., Sutter T. R., Proc. Natl. Acad. Sci. U.S.A., 93, 9776-9781 (1996).

67) Pang S., Cao J. Q., Katz B. H., Hayes C. L., Sutter T. R., Spink D. C., Biochem. Pharmacol., 58, 29-38 (1999). 